\title{
Fraud Phenomenon in The Government Sector in Indonesia
}

\author{
Sudrajat Sudrajat ${ }^{1}$, Rindu Rika Gamayuni ${ }^{2}$, Lailatul Qodry ${ }^{3}$ \\ \{Sudrajat.1973@feb.unila.ac.id ${ }^{1}$, Rindu.gamayuni@yahoo.com ${ }^{2}$, qodrilt@gmail.com $\left.{ }^{3}\right\}$ \\ Faculty Economic and Business, Universitas Lampung, Indonesia ${ }^{1,2,3}$
}

\begin{abstract}
This study aims to prove the factors that can reduce fraud in the public sector in Indonesia, especially in Lampung Province. Fraud is an action that endangers the sustainability of an organization because the organization will massively be destroyed when fraudulent practices cannot be detected. Collecting data in this study through a questionnaire with respondents internal and external auditors of local government in Lampung Province. The data were processed using the PLS Structural Equational Model (SEM). The results showed that gender and task complexity did not affect fraud. The audit process is conducted in accordance with State Financial Audit Standards so that whoever carries out the audit, will give the same conclusion. The complexity of the auditor's duties does not affect fraud practice. When the auditor has several duties, the completion process will always go through the supervision of the supervisor so that the audit process still in high quality.
\end{abstract}

Keywords: fraud, gender, task complexity

\section{INTRODUCTION}

Fraud is the root cause of organizational damage due to fraud and deliberate fraud for the benefit of certain individuals or groups. The organization will be massively weakened by internal parties who are supposed to raise and maintain the sustainability of its business. [1]. Fraud in Indonesia is still quite high compared to other countries in ASIA. This is indicated by the Corruption Perception Index (CPI) score. Indonesi a's CPI in 2018 was 3.6 out of the ideal score of 10, while Malaysia and Singapore were 4.9 and 8.4, respectively.Another phenomenon shows that the corruption of local government financial budgets in Indonesia reaches $20 \%-40 \%$, [2] This condition shows the proliferation of fraudulent practices that are difficult to eliminate. The fraud occurred in almost all local governments including regional governments in the province of Lampung, including a fraud case in North Lampung Regency which caused losses to the state finances amounting to Rp. 1.7 billion, [3]. Various efforts have been made by the organization to eliminate fraud, especially in the financial management of local governments, such as the establishment of internal control and supervision, namely the Financial and Development Supervisory Agency (BPKP) through Law No. 60 of 2008 concerning Government Internal Control Systems and external audits, namely the Audit Board (BPK). Various audit provisions and procedures are designed in detail to detect fraud that occurs. In the audit process, this institution also applies a gender-based auditor task system. This is intended to determine the level of success in disclosing or finding fraud in the audit process. However, it cannot be concluded surely that the success of disclosing fraud in the audit process is based on gender. The results also show that gender is still inconsistent with the effect of gender on reducing fraud rates, [4]; [5].

Besides gender, other factors that can affect audit effectiveness in reducing fraud are the number of tasks and responsibilities of auditors at the same time, in other words, auditors have a high level of task complexity [6]. The complexity of the auditor's task greatly affects the accuracy and thoroughness of the audit process. The higher the level of complexity of the auditor's duties, the weaker the ability to reveal fraud. This has increased fraud [7]. The results of research by [6] found 
that even though auditors are in high task complexity because in carrying out the duties, the auditors are always based on the principles of independence, honesty, courage, wisdom, and responsibility in decision making, task complexity does not affect increasing fraud. Based on this phenomenon, research related to the influence of gender and the complexity of the auditor's duties on fraud is still interesting to do.

\section{LITERATURE REVIEW AND HYPOTHESIS DEVELOPMENT}

\subsection{Related Literature}

The first variable as the dependent variable in this study is a fraud, a phenomenon that is the main topic of discussion in Indonesia. Fraud is a fraud that includes elements such as a representation, regarding something that is material, something that is not true and is deliberately or carelessly done to then be trusted and acted upon by the victim so that in the end the victim bears the loss [8]. Meanwhile, according to [1] fraud is a deliberate fraudulent [4] by taking assets or rights of other people or parties. [9] revealed that the factors that cause fraud are: opportunity, pressure, and rationalization. These three factors are better known as the "Fraud Triangle". Fraudulent practices in various organizations continue to increase due to various causes. This condition is in accordance with the findings of [10] who developed the Fraud Triangle theory into a "Fraud Diamond" by adding the competency factor as one of the triggers for fraud. In 2011, Crowe redeveloped the factors that led to organized fraud under the term "Pentagon fraud". The concept of the fraud pentagon in this theory changes the risk factor element in the fraud diamond theory, namely capability to become competent but still has the same meaning, and adds another element of fraud which is believed to have a significant effect on fraud, namely arrogance. In this study, fraud is measured by using the fraud pentagon indicators consisting of Pressure, Opportunity, Rationalization, Competence / Capability, and Arrogance.

The second variable is Gender. It is a cultural concept that differentiates between men and women in terms of their roles, behavior, mental, and emotional characteristics in completing a job. Gender in this study is associated with the audit process carried out by male and female auditors because there is a view that male auditors are more assertive and have positive connotations, while female auditors are weak and less assertive [11]. The same thing was conveyed by [5], that. men and women tend to have different ways of completing the audit process. When the burden of information increases, women are more careful in carrying out their duties and making decisions so that it takes longer. This is different from male auditors who can complete work and make decisions faster. In this study, gender is measured by the following indicators [12]: basic skills and analysis, technical abilities, and mental attitudes.

The third variable is the complexity of the task, which is related to a person's ability to coordinate and complete work normally in situations where many jobs are charged and must be completed at the same time [7]. Task complexity is based on the individual's perception of the difficulty in completing the job. The process of completing tasks is becoming increasingly complex due to the increasing level of difficulty (task difficulty) and task variability. Regarding the audit process, the unchanging task demands imposed on auditors make auditors feel bored and quickly get bored. This can cause complex problems for auditors to disclose findings during the audit process related to fraud that occurred in the organization being examined. Task complexity in this study is measured by indicators of difficulty level and task variability [12]. 


\subsection{Hypothesis Development \\ The Effect of Gender Auditor on Fraud}

Research Results [12] found that women were better able to process multiple and / or inconsistent cues, make better distinctions between similar cues, recall cues, and integrate cues. As a consequence, women can make more accurate judgments than men because of their better processing of comprehensive information than men. [5] found that female auditors have a positive influence on the quality of audit services. Other research results by [13] also state the same thing that female auditors are more careful in revealing irregularities with accurate evidence. Based on the premise in the form of theory and previous research, the hypothesis is formulated as follows:

$\mathrm{H}_{1}$ : The task of female auditors has a negative effect on fraud.

\section{The Effect of Task Complexity on Fraud}

The results of [14] study found that when the complexity of a person's task increases, that person will use an easier strategy or take a path that is detrimental and will lead to lower quality and decisions, in this case, it can be interpreted. If the complexity of the auditor's duties increases, it will decrease their effectiveness in carrying out audit procedures and in making decisions. Low audit quality is not able to reveal fraud that occurs in the organization being audited. This will lead to an increase in fraud that occurs in the organization. The results of research by [12] found that there was a significant influence between audit complexity and fraud fluctuations. Based on this premise, the following hypothesis is formulated:

$\mathrm{H}_{2}$ : The complexity of the auditor's duties has a positive effect on fraud

\section{METHODOLOGY AND DATA ANALYSIS}

This research is a causality study that examines the effect of gender and the complexity of the audience's task in reducing the level of fraud. The data used are primary data through questionnaires with auditor respondents at the Supreme Audit Agency and the Development and Finance Supervisory Agency in Lampung Province. The auditors who are used as the sample are investigative auditors' special research because these auditors are tasked with examining specific matters, usually related to fraud. The questionnaire is designed to obtain a real picture of what is happening in the field. The collected data were analyzed with the Structural Equational Model-Partial Least Square (SEM-PLS).

\section{RESEARCH RESULT AND DISCUSSION}

\subsection{Research Results}

The questionnaire distributed to respondents was 65 and 45 returned and can be processed. The response rate was $69 \%$ so that the sample was feasible to be tested. Judging from the characteristics of the respondents, as many as 19 people (42\%) were male respondents and 25 people (58\%) were female respondents.

The results of data processing to test the hypothesis in this study are presented in Figure 1 as follows: 


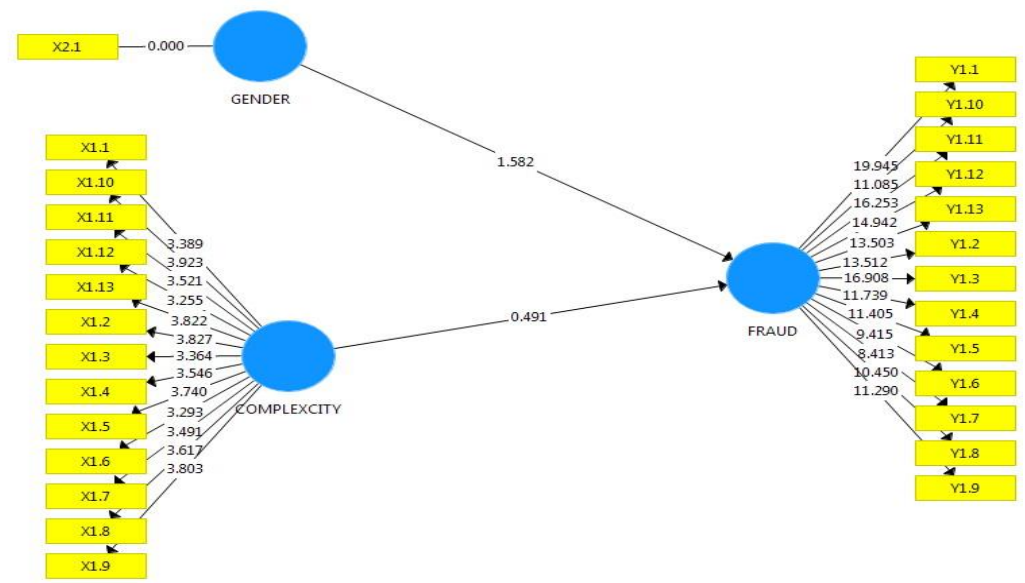

Fig. 1. Hypothesis Testing Results

Based on the results of hypothesis testing, it can be seen that the coefficient of gender influence on fraud is 1.582 smaller than 1.96 so that it can be concluded that $\mathrm{H}_{1}$, namely, the female gender has a negative effect on fraud is rejected. The results of testing the second hypothesis (H2) with a coefficient value of 0.491 are smaller than 1.96 so that it can be concluded that the hypothesis is rejected.

\subsection{Discussion}

The results of research related to differences between men and women in conducting the audit process in the government environment in reducing the level of fraud are not proven. This shows that both male and female auditors in carrying out their duties have been based on standard rules, namely the State Financial Audit Standards (SPKN) so that whoever carries out the audit process in the organizational unit will give the same results. All auditors to be assigned to investigative audits must meet certain qualities that are obtained only through special education and training. The results of this training are provisions for carrying out the audit process following the SPKN. The results of this study do not support previous studies conducted by [12], [5], [13].

Regarding task complexity, the results of this study do not support [14] statement which states that if the complexity of a person's task increases, then that person will use an easier strategy, or take a detrimental path and will lead to lower quality and decisions. The results of the questionnaire analysis and interviews with respondents indicate that each investigation audit task is always assigned by an independent audit team so that the audit process is carried out in stages from the executive auditor, supervisor to the quality control team. This is to ensure that the audit process has been carried out according to procedures. Besides, the SPKN has required people who can be assigned and the competencies that must be possessed in each task. When an auditor is assigned more than one task, the supervisor is always supervising the implementation of these tasks so that the audit quality can be maintained.

\section{CONCLUSION}

Based on the findings and test results it can be concluded that gender factors and audit complexity are not things that can increase the accuracy of the audit process because the audit process must be based on the SPKN. Anyone who complements when following the SPKN will give the same 
conclusion and when the auditor has high task complexity, the quality of the audit must be prioritized through supervision and audit quality assurance.

\section{LIMITATION AND SUGGESTIONS FOR FURTHER RESEARCH}

This research was conducted at the time of the COVID-19 epidemic so that researchers could not conduct maximum interviews with respondents. Researchers are only based on the results of a questionnaire analysis with several respondents who could be contacted by telephone. Future research can develop a broader unit of analysis such as local governments in the Sumatra Islands or throughout Indonesia.

\section{References}

[1] A. Hobson, Auditing and Assurance Service. 2005.

[2] "Diningsih 2019-Fraud in Indonesia.".

[3] "BPK RI 2019-Fraud Detection in Local Government." .

[4] K. Hardies, D. Breesch, and J. Branson, "Are Female Auditors Still Women? Analyzing the Sex Differences Affecting Audit Quality,” SSRN Electron. J., 2011, doi: 10.2139/ssrn.1409964.

[5] J. Garcia-Blandon, J. M. Argilés-Bosch, and D. Ravenda, "Is there a gender effect on the quality of audit services?,” J. Bus. Res., 2019, doi: 10.1016/j.jbusres.2018.11.024.

[6] I. Sukriyah, Akram, and B. A. Inapty, "Pengaruh Pengalaman Kerja, Independensi, Obyektifitas, Integritas dan Kompetensi Terhadap Kualitas Hasil Pemeriksaan Oleh:," Pengaruh Pengalaman Kerja, Indep. Obyektifitas, Integritas dan Kompetensi Terhadap Kualitas Has. Pemeriksaan, 2009.

[7] C. D. Cahyaningrum and I. Utami, "DO OBEDIENCE PRESSURE AND TASK COMPLEXITY AFFECT AUDIT DECISION?,” J. Akunt. dan Keuang. Indones., 2015, doi: 10.21002/jaki.2015.06.

[8] H. S. Lee, A. L. Nagy, and A. B. Zimmerman, "Audit partner assignments and audit quality in the United States," Account. Rev., 2019, doi: 10.2308/accr-52218.

[9] R. Kassem and A. Higson, "The New Fraud Triangle Model," J. Emerg. Trends Econ. Manag. Sci., 2012.

[10] D. T. Wolfe and D. R. Hermanson, "The Fraud Diamond : Considering the Four Elements of Fraud," $C P A$ J., 2004, doi: DOI:

[11] J. Winarna and H. Mabruri, "Analisis Faktor-Faktor Yang Mempengaruhi Kualitas Hasil Audit Di Lingkungan Pemerintah Daerah,” J. Rural Dev., 2015.

[12] M. Nekhili, F. Javed, and T. Chtioui, "Gender-diverse audit partners and audit fee premium: The case of mandatory joint audit," Int. J. Audit., 2018, doi: 10.1111/ijau.12133.

[13] J. S. Clancy and N. Mohlakoana, "Gender audits: An approach to engendering energy policy in Nepal, Kenya and Senegal,” Energy Res. Soc. Sci., 2020, doi: 10.1016/j.erss.2019.101378.

[14] S. E. Bonner, "A model of the effects of audit task complexity," Accounting, Organ. Soc., 1994, doi: 10.1016/0361-3682(94)90033-7. 